\title{
PENETRATION OF CEFOTAXIME INTO INTER- VERTEBRAL DISCS REMOVED FROM PATIENTS UNDERGOING DISCECTOMY
}

\author{
Thamer A Hamdan ${ }^{@}$, Mohammed S Hashim", Nazar S Haddad* \& \\ Abdullah M Jawad ${ }^{\wedge}$
}

${ }^{\circledR}$ FRCS, FICS, FACS, FRCP, American Board of Neurological \& Orthopedic Surgery, Professor of Orthopedic Surgery. "MSc student, Department of Pharmacology. "Assistant Professor of Chemical Pathology. ^Professor of Pharmacology, College of Medicine, University of Basrah, Basrah, IRAQ.

\begin{abstract}
The intervertebral disc is an avascular tissue, and penetration of antibiotics occurs by passive diffusion. Cefotaxime penetration has not been well studied. The aim is to investigate the penetration of cefotaxime into the intervertebral disc removed from patients undergoing discectomy.

Twenty-six patients undergoing discectomy were recruited for this study. They were given one gram of cefotaxime intravenously as a prophylactic antibiotic. Cefotaxime was extracted from nucleus pulposus and serum and analyzed using an HPLC method with cefuroxime axetil as internal standard.

Cefotaxime penetrated into all the 26 samples of nucleus pulposus resulting in a mean concentration of $0.66 \pm 0.13 \mu \mathrm{g} / \mathrm{gm}$. The mean serum concentration at time of disc removal was $13.61 \pm 3.54 \mu \mathrm{g} / \mathrm{ml}$. The concentration in 16 samples were below the minimum inhibitory concentration against Staph. aureus with an average of $0.27 \pm 0.03 \mu \mathrm{g} / \mathrm{g}$. There is a statistically significant correlation between time after intravenous cefotaxime administration and its concentration in the nucleus pulposus. The greater increase is in the third hour after administration. Factors like age, body weight, gender, number of associated diseases and surgical history did not seem to affect nucleus pulposus cefotaxime concentration.

In conclusion, cefotaxime can penetrate into the nucleus pulposus but its concentration is relatively low. This concentration has a strong positive correlation with time after cefotaxime intravenous administration. Cefotaxime, therefore, needs to be given at least two hours before disc removal, with re-dosing immediately before operation to maintain high serum concentration. Keywords: Surgery, cefotaxime concentration, intervertebral disc, nucleus pulposus, discectomy
\end{abstract}

\section{Introduction}

$\mathrm{T}$ he intervertebral disc is an avascular tissue and the only way for antibiotics to reach the core of the disc is by passive diffusion ${ }^{1}$. If antibiotics do not reach the inner part of the disc (nucleus pulposus, NP) in a sufficient concentration that exceeds the minimal inhibitory concentration (MIC) of the causative micro-organism, it may not protect against infections during discectomy and may result in discitis and failure of operation ${ }^{2}$. Several antibiotics were found to have good penetration into the intervertebral disc such as ceftriaxone, ceftazidime and cefazolin $^{3-6}$, cefuroxime \& gentamicin ${ }^{7-8}$,

clindamycin and tobramycin ${ }^{9-10}$, vancomycin $^{11}$ and several others. On the other hand, antibiotics like linezolid ${ }^{12}$, ciprofloxacin, co-amoxiclav and amoxicillin $^{13,14}$, cefalothin ${ }^{9}$, and cefradine and flucloxacillin ${ }^{14}$ had intermediate or low penetration. Scarce information is available about the penetration of cefotaxime; one of the antibiotics used in orthopedic practice in Basrah, into the intervertebral discs. The aim of the present study is, therefore, to investigate the penetration of cefotaxime into the intervertebral disc removed from patients undergoing discectomy and to relate that to its serum concentration and time 
between cefotaxime administration and disc removal, and also to several other patient characteristics.

\section{Patients and Methods}

Twenty-six patients underwent discectomy at Basrah General Hospital and Ibn-Albitar Hospital during the period from October 2014 to June 2015, were recruited after giving their informed consent to participate in this study. The study protocol was approved by the Ethical Committee and the Council of the College of Medicine, University of Basrah. Patients were given cefotaxime (Cefotaxime sodium 1g, Roth, Germany) intravenously as a prophylactic antibiotic within one hour before surgery. Male and female patients, less than 65-year-old with no history of hypersensitivity reaction to cephalosporins or penicillins were included. Patients should have no renal impairment by history and investigations. Venous blood samples were taken from eligible patients before cefotaxime administration and also at time of disc removal. Serum was separated and stored at -40 C. Specimens of the nucleus pulposus were washed with normal saline to remove contaminating blood, and stored in a plastic container at $-40 \dot{C}$. Cefotaxime was extracted from serum samples and analyzed by HPLC based on the method

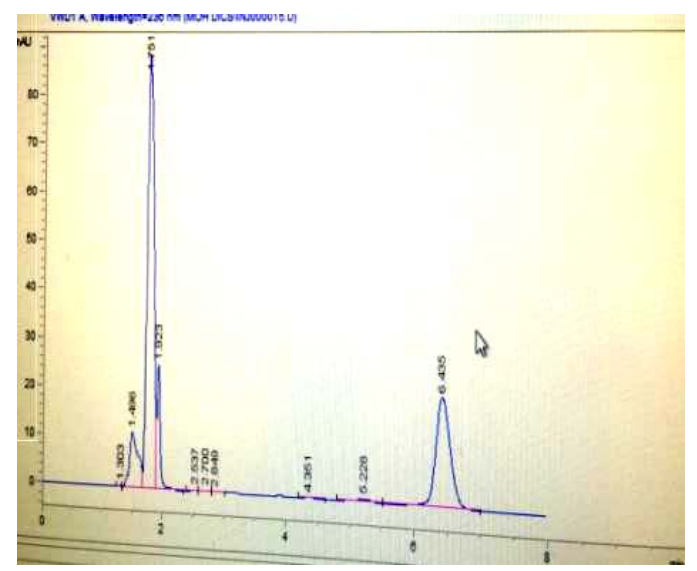

(A) Cefuroxime axitel described by Shanmugam et $\mathrm{al}^{15}$. Acetonitrile was used for extraction after addition of cefuroxime axetil as internal standard, diluted with mobile phase, and $50 \mu 1$ were injected into the HPLC apparatus. The nucleus pulposus was weighed and cut into pieces and homogenized with acetonitrile in a ratio of $1: 6 \mathrm{w} / \mathrm{v}$ using Hedoliph homogenizer, and after addition of cefuroxime axetil as internal standard, vortexed and the supernatant was air-dried in a water bath

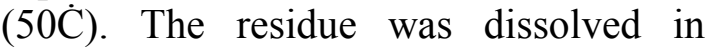
$100 \mu 1$ of the mobile phase, vortexed and $50 \mu 1$ were injected into the HPLC, in a similar method to that described by Walters et al16 (Figure 1). The mobile phase was ammonium acetate buffer: acetonitrile $88: 12 \mathrm{v} / \mathrm{v}, \mathrm{pH} 5$, temperature $25 \dot{C}$, flow rate $1 \mathrm{ml} /$ minute, wavelength $236 \mathrm{~nm}$. Quantitation was achieved by measurement of the peak height ratio of the drug to the internal standard. The intraday coefficient of variation $(\mathrm{CV})$ of the internal standard for serum samples was $5.98 \%$ while that for disc samples $9.38 \%$. The lower limit of quantitation was $0.2 \mu \mathrm{g} / \mathrm{ml}$. Data are presented as mean \pm standard error of the mean (SEM) or as indicated. Analysis of variance (ANOVA) and t-test were used to test the significance of changes between different related variables and Exact Fisher test was used for categorical data.

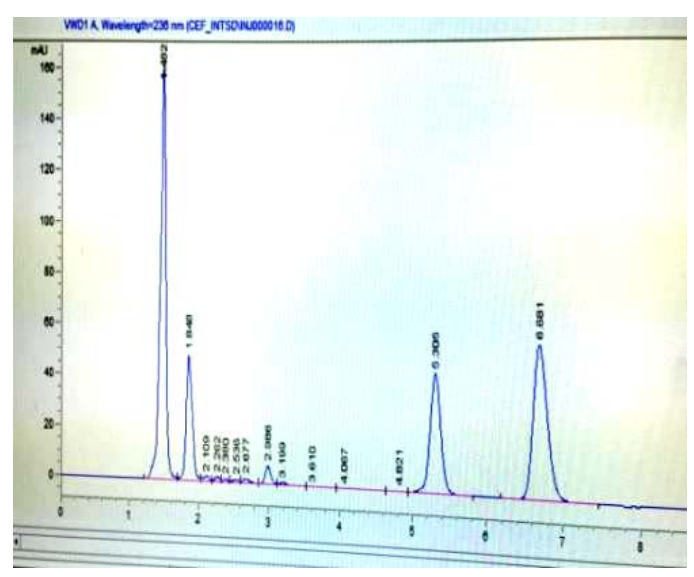

(B) cefotaxime with cefuroxime axitel

Figure 1: The chromatogram of blank serum with cefuroxime axetil at a concentration of $2 \mathrm{mg} / \mathrm{ml}$ as internal standard (A). Cefotaxime sodium at a concentration of $1 \mu \mathrm{g} / \mathrm{ml}$ with cefuroxime axetil $(2 \mathrm{mg} / \mathrm{ml})$ (B). The retention time is 5.3 minutes for cefotaxime sodium and 6.6 minutes for cefuroxime axetil. 


\section{Results}

Twenty-six patients undergoing discectomy (20 with lumbar and 6 with cervical disc prolapse) were included in this study, with a mean age of $47 \pm 2.35$ years; 19 of them were males and 7 females, with a mean body weight of $83.38 \pm 2.21 \mathrm{Kg}$. Most of them were using anti-inflammatory and analgesics drugs like NSAIDs and other treatments (antihypertensive and anti-diabetic drugs) and the average number of drugs used by each patient was $3.11 \pm 0.08$. The average number of spine surgeries that patients underwent was $1.23 \pm 0.19$ (Table I).

Table I: Characteristics of patients included in this study

\begin{tabular}{|l|l|l|l|l|l|l|}
\hline $\begin{array}{c}\text { Site } \\
\text { of prolapse }\end{array}$ & $\begin{array}{c}\text { Age } \\
\text { (years) }\end{array}$ & $\begin{array}{l}\text { Male/ } \\
\text { Female } \\
\text { ratio }\end{array}$ & $\begin{array}{l}\text { Weight } \\
(\mathrm{Kg})\end{array}$ & $\begin{array}{l}\text { Number of } \\
\text { Associated } \\
\text { diseases }\end{array}$ & $\begin{array}{l}\text { Number of } \\
\text { drugs Used }\end{array}$ & $\begin{array}{l}\text { Surgical } \\
\text { history } \\
1^{\text {st }} \text { or } 2^{\text {nd }} \\
\text { surgery }\end{array}$ \\
\hline $\begin{array}{l}\text { Lumbar } \\
\text { prolapse } \mathrm{n}=20\end{array}$ & $\begin{array}{l}44 \\
\pm 2.38\end{array}$ & $\begin{array}{l}14 \mathrm{M} / 6 \mathrm{~F} \\
(2.33)\end{array}$ & $\begin{array}{l}80.75 \\
\pm 2.58\end{array}$ & $0.83 \pm 0.13$ & $3.2 \pm 0.09$ & $\begin{array}{l}16-1 \mathrm{st} \\
4-2 \mathrm{nd}\end{array}$ \\
\hline Cervical & 54 & $5 \mathrm{M} / 1 \mathrm{~F}$ & 89.66 & 0 & $3 \pm 0$ & $\begin{array}{l}5-1 \mathrm{st} \\
1-2 \mathrm{nd}\end{array}$ \\
prolapse $\mathrm{n}=6$ & \pm 5.82 & $(5.0)$ & \pm 3.38 & & & \\
\hline Total & 47 & $19 \mathrm{M} / 7 \mathrm{~F}$ & 83.38 & $0.31 \pm 0.107$ & $3.11 \pm 0.08$ & $1.23 \pm 0.19$ \\
$\mathrm{n}=26$ & \pm 2.35 & $(2.71)$ & \pm 2.21 & & & \\
\hline
\end{tabular}

Data are presented as mean \pm SEM.

Cefotaxime in NP and serum samples:

Cefotaxime was detected in nucleus pulposus of all discs removed from the 26 patients undergoing laminectomy with wide variation between patients (mean \pm SEM was $0.66 \pm 0.13 \mu \mathrm{g} / \mathrm{g}$ ). No cefotaxime was detected in serum

samples collected before injection. Cefotaxime in serum at time of disc removal was detected in 22 samples and there was wide variation between patients $(13.61 \pm 3.54 \mu \mathrm{g} / \mathrm{ml})$.

Serum concentration was negatively correlated with the time after antibiotic administration

(Table

II).

Table II: Time for disc collection with relevant serum and nucleus pulposus cefotaxime concentrations

\begin{tabular}{|c|c|c|c|}
\hline $\begin{array}{c}\text { Duration of disc } \\
\text { removal (minutes)* }\end{array}$ & $\begin{array}{c}\text { Number of } \\
\text { patients }\end{array}$ & $\begin{array}{c}\text { Nucleus pulposus } \\
\text { concentration }(\mu \mathrm{g} / \mathrm{g})\end{array}$ & $\begin{array}{c}\text { Serum } \\
\text { Concentration }(\mu \mathrm{g} / \mathrm{ml})\end{array}$ \\
\hline$\leq 30$ & 2 & $0.12 \pm 0.02$ & $39.6 \pm 30.35$ \\
\hline $35-60$ & 5 & $0.22 \pm 0.05$ & $21.46 \pm 9.96$ \\
\hline $65-120$ & 15 & $0.5 \pm 0.07$ & $11.6 \pm 2.97$ \\
\hline $125-180$ & 4 & $2.08 \pm 0.2$ & $0.36 \pm 0.14$ \\
\hline $86.15 \pm 7.15$ & 26 & $0.66 \pm 0.13$ & $13.61 \pm 3.54$ \\
\hline
\end{tabular}

Data are presented as means \pm SEM. * After cefotaxime administration

Cefotaxime concentration in nucleus pulposus: Cefotaxime concentrations in nucleus pulposus were, arbitrarily, categorized into two groups: below and above the minimum inhibitory concentration (MIC) against Staph. aureus (Table III) (Note: For the sake of categorization, and because of the semifluid nature of the NP, units of NP concentration in $\mu \mathrm{g} / \mathrm{g}$ are roughly taken to be equivalent to $\mu \mathrm{g} / \mathrm{ml})$. Serum concentration was significantly lower in the group with higher than MIC cefotaxime concentration in the NP $(\mathrm{P}=0.035)$. The longer the duration after cefotaxime administration, the lower the serum concentration and the higher the NP concentration. Other variables like age, weight, gender, number of associated diseases, number of drugs used by patients, surgical history (1st or 2 nd operation) were not significantly different 
between the two groups. However, female patients tended to have proportionally more second operations and less cervical prolapse, in comparison to males. Cefotaxime concentration in NP of cervical discs was found to be higher than that in lumbar discs. This difference had just failed to reach statistical significance $(\mathrm{P}=0.073)$. The duration till disc removal was longer in cervical laminectomy but the difference was not statistically significant (table III): Concentration of cefotaxime in nucleus pulposus above and below the MIC against Staph. aureus $(0.5 \mu \mathrm{g} / \mathrm{ml})$.

Table III: Concentration of cefotaxime in nucleus pulposus above and below the MIC against Staph. aureus $(0.5 \mathrm{\mu g} / \mathrm{ml})$

\begin{tabular}{|c|c|c|c|}
\hline \multirow[t]{2}{*}{ Parameter } & \multicolumn{2}{|c|}{ NP concentration } & \multirow[t]{2}{*}{$\mathrm{P}$ value } \\
\hline & $\begin{array}{l}\text { Below MIC against } \\
\text { Staph. aureus* } n=16\end{array}$ & $\begin{array}{l}\text { Above MIC against } \\
\text { Staph. aureus* } n=10\end{array}$ & \\
\hline Mean \pm SEM & $0.27 \pm 0.03$ & $1.29 \pm 0.23$ & \\
\hline Serum conc. $(\mu \mathrm{g} / \mathrm{ml})$ & $18.84 \pm 5.16$ & $5.25 \pm 2.63$ & 0.035 \\
\hline Duration (minutes) & $68.75 \pm 6.46$ & $114 \pm 11.61$ & 0.001 \\
\hline Male/Female ratio & 3 & 2.33 & \\
\hline Age (years) & $48 \pm 3.29$ & $45 \pm 3.2$ & 0.457 \\
\hline Body weight (kg) & $83.87 \pm 3.1$ & $82.6 \pm 3.1$ & 0.774 \\
\hline $\begin{array}{l}\text { No. of chronic } \\
\text { diseases }\end{array}$ & $0.33 \pm 0.15$ & $0.27 \pm 0.13$ & 0.881 \\
\hline $\begin{array}{l}\text { Surgical history } \\
\text { (1st or } 2 \text { nd) }\end{array}$ & $14-1$ st 2-2nd & $\begin{array}{l}8-1 \mathrm{st} \\
2-2 \mathrm{nd}\end{array}$ & \\
\hline No. of drugs used & $3.2 \pm 0.06$ & $3.1 \pm 0.1$ & 0.94 \\
\hline
\end{tabular}
concentration and time after its concentration was found to increase as administration: The time between the time after administration became cefotaxime intravenous administration longer (Pearson correlation coefficient and disc removal correlated positively $\mathrm{r} 2=0.6844, \quad \mathrm{P}=0.000$ ) (Figure 2). and significantly with NP cefotaxime

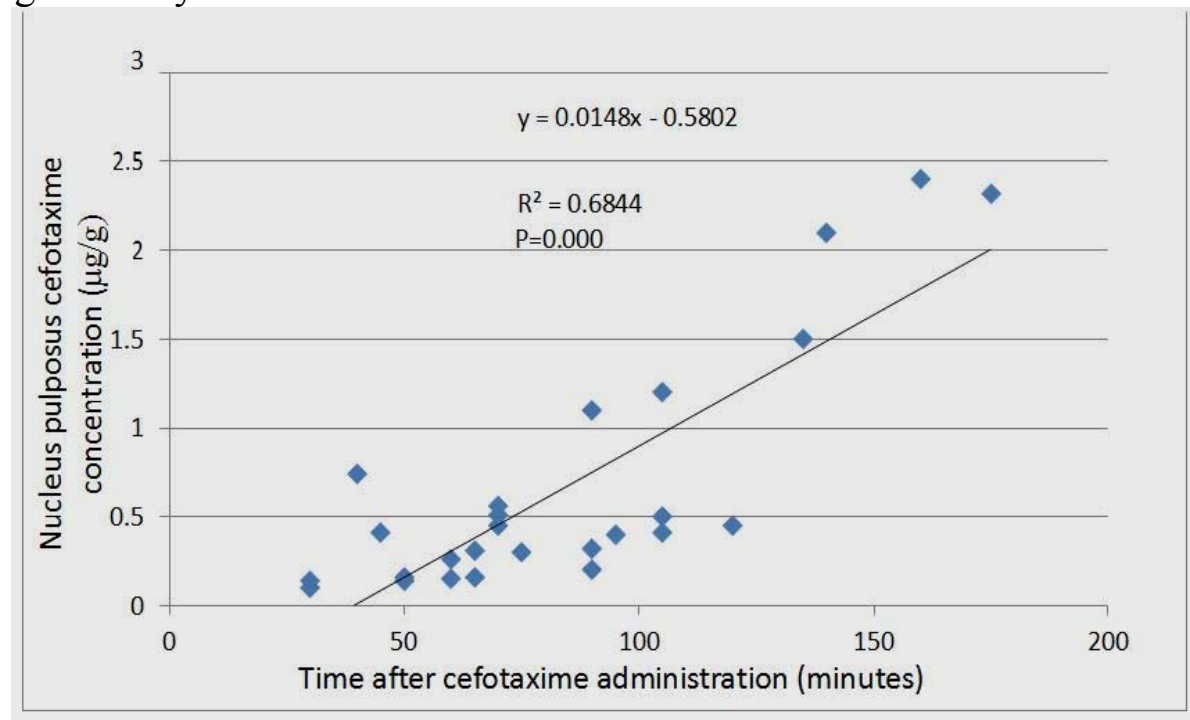

Figure 2: Correlation of NP cefotaxime concentration with time after administration. 
The ratio of cefotaxime serum and NP concentration to its minimum inhibitory concentration (MIC) against Staph. aureus. The ratio of serum and NP concentration to the MIC against Staph. aureus was calculated as a sensitive index for the effectiveness of an antibiotic. The ratio of mean serum concentration to the MIC (against Staph. aureus) was 27.22, while that of nucleus pulposus concentration was only 1.32 (Table

IV).

Table IV: The ratio of serum and NP concentration of cefotaxime to MIC against S. aureus.

\begin{tabular}{|l|l|l|}
\hline Parameters & Mean concentration & Ratio to MIC \\
\hline Serum & $13.61 \mu \mathrm{g} / \mathrm{ml}$ & 27.22 \\
\hline NP & $0.66 \mu \mathrm{g} / \mathrm{g}^{*}$ & 1.32 \\
\hline $\begin{array}{l}\text { MIC of cefotaxime against } \\
\text { Staph. aureus }\end{array}$ & $0.5 \mu \mathrm{g} / \mathrm{ml}$ & - \\
\hline
\end{tabular}

*For the sake of comparison and categorization (above and below MIC), and because of the semifluid nature of the NP, the $\mu \mathrm{g} / \mathrm{g}$ concentration is roughly taken to be equivalent to $\mu \mathrm{g} / \mathrm{ml}$.

\section{Discussion}

The importance of the subject of antibiotic penetration into the intervertebral disc stems from the serious consequences of the disc space infection that might occur after discectomy, with an estimated incidence rate ranging from 0.21 to $3.6 \%{ }^{17-20}$. Prevention of infection is, therefore, of utmost importance. The main problem is that the intervertebral disc and its nucleus pulposus are avascular tissues ${ }^{21}$. They receive their nutrition and get rid of waste products via the process of diffusion ${ }^{1}$. This diffusion depends on several factors which include, among others, drug molecular charge, protein binding, serum concentration, time after administration and disc degeneration ${ }^{5-7,10,22}$. For the antibiotic to be effective in preventing infection, it must penetrate into the disc in a concentration above the minimal inhibitory concentration (MIC) of the causative bacteria $^{23}$. The penetration of cephalosporins into the intervertebral discs has been studied previously. Cefazolin, a first generation cephalosporin, is extensively studied on the basis of its effectiveness against gram positive organisms particularly Staph. aureus which is an important causative organism of disc space infection ${ }^{19,24}$.
Cefazolin is thought to be the preferred cephalosporin used for prophylaxis prior to spine surgery ${ }^{25}$. Ceftriaxone, a third generation cephalosporin with its broad spectrum activity and long duration of action, has also been studied ${ }^{5}$. On the other hand, cefradine and cefalothin could not be detected in the nucleus pulposus ${ }^{9,14}$.

Up to our knowledge, cefotaxime penetration into intervertebral discs has not been well investigated in human or animals despite its common prescription particularly in our local orthopedic practice. Therefore, $1 \mathrm{~g}$ of cefotaxime was given intravenously at different intervals before spine surgeries, and its concentration in the nucleus pulposus removed during surgery, and serum concentration at time of NP removal, were measured by HPLC methods. Results of the present study showed that cefotaxime when given intravenously as a prophylactic antibiotic before discectomy penetrates into the intervertebral disc and reaches, to a variable extent, the nucleus pulposus in all the 26 disc samples received after discectomy with a mean concentration of $0.66 \pm 0.13 \mu \mathrm{g} / \mathrm{g}$, while the mean serum concentration at time of disc removal was $13.61 \pm 3.54 \mu \mathrm{g} / \mathrm{ml}$. This 
NP concentration is relatively low with 16 patients $(61.5 \%)$ were having a concentration below the MIC against Staph. aureus. The overall approximated ratio of NP concentration to the MIC against Staph. aureus is only 1.32 , compared with 27.22 for serum. As cited above, one factor influencing penetration is the electrical charge of the antibiotic molecule ${ }^{7}$. Positively charged antibiotics e.g. aminoglycosides penetrate easily to the negatively charged NP. Cephalosporins are negatively charged compounds. They have less capability to penetrate in comparison to aminoglycosides ${ }^{13}$. Cephalothin and cefradine are negatively charged and had not be detected in the $\mathrm{NP}^{9,14}$. Time after administration seems to affect antibiotic penetration into the nucleus pulposus ${ }^{3}$. Gentamicin needed around two hours after its administration to reach its peak in the nucleus pulposus $^{26}$. Cefazolin required one hour after administration to reach its peak level ${ }^{16}$. In the present study, cefotaxime concentration in the nucleus pulposus is significantly correlated with the time after its intravenous administration. The NP concentration increased 2 hours after cefotaxime concentration. During the 3rd hour after cefotaxime administration, the average concentration increased from $0.5 \pm 0.07 \mu \mathrm{g} / \mathrm{g}$ to $2.08 \pm 0.2 \mu \mathrm{g} / \mathrm{g}$ while serum concentration was decreasing with time. The relationship between NP and serum concentrations was negative. The results of the present study indicate that for higher NP concentration, cefotaxime should be administered 2 hours and more before disc removal. In line with our results, Lang et $\mathrm{al}^{3}$, reported that effective ceftriaxone NP concentration after intravenous administration was achieved after 2-4 hours, while Currier et $\mathrm{al}^{26}$, showed that gentamicin level in the NP peaked 2 hours after intravenous bolus administration. However, opposite findings had been reported by Fraser et $\mathrm{al}^{27}$, where longer time after cefazolin administration will have a negative effect on its concentration in the nucleus pulposus. Several other factors could be responsible for the poor penetration detected in the remaining 16 patients in the present work. One of them is the protein binding. High protein binding of cefotaxime $(>90 \%)$ can play an important role in slowing penetration. This is in contrast to gentamicin which has a low protein binding (20-30\%) with good penetration property ${ }^{13}$. The ratio of serum or NP concentration to the minimum inhibitory concentration (MIC) is considered as a sensitive indicator of the effectiveness of an antibiotic $^{15}$. In the present study, the ratio of NP concentration to the MIC against Staph. aureus was small indicating poor penetration of cefotaxime to the disc. The dose of cefotaxime used in this study is one gram. Increasing the dose might be tried in the future because the evidence is that increased penetration can occur after increasing the antibiotic dose, particularly for longer operations. Lang et $\mathrm{al}^{3}$, Riley et $\mathrm{al}^{7}$ and Rohde et $\mathrm{al}^{8}$ suggested that larger bolus doses are required for operations longer than 4 hours to maintain effective levels. In addition, cefoperazone reached a detectable level exceeding the MIC against Staph.aureus only if given in a dose of $2 \mathrm{~g}^{28}$. It is, therefore, concluded that cefotaxime can be detected in the nucleus pulposus of all patients involved in this study, but its concentration is relatively low. A strong positive correlation was found between time after cefotaxime intravenous administration and its concentration in the nucleus pulposus. The greater increase is in the third hour after administration. Cefotaxime, therefore, needs to be given at least two hours before the expected time for disc removal, with re-dosing immediately before operation to maintain high serum concentration. 


\section{References}

1.Osti OL, Vernon-Roberts B, Fraser RD (1990) Discitis after discography. The role of prophylactic antibiotics. Spine 15:762-767. PMI:2312567

2. Motaghinasab S, Shirazi-Adl A, Urban JP, Parnianpour M (2012) Computational pharmacokinetics of solute penetration into human intervertebral discs - effects of endplate permeability, solute molecular weight and disc size. J Biotech 45:2195-2202. doi: 10.1016/j.jbiomech. 2012.06.033.

3. Lang R, Folman Y, Ravid M, Bental T, Gepstein R (1994) Penetration of ceftriaxone into the intervertebral disc. J Bone Joint Surgery 76:689-691. PMID: 8175816

4. Walters R, Rahmat R, Fraser R, Moore R (2006) Preventing and treating discitis: cephazolin penetration in ovine lumbar intervertebral disc. Eur Spine J 15: 1397-1403. PMID: 16830132

5. Lin CC, Wu YT, Yen JC, Chiang CJ, Tsuang YH, Tsai TH (2010) In vitro and in vivo methods to measure the ceftriaxone distribution into the rat tail intervertebral disc. Anal Scio 26:979-982. PMID: 20834130

6. Yan D, Li J, Zhang Z, Zhu H (2012) Determination of cephazolin, ceftazidime, and ceftriaxone distribution in nucleus pulposus. Arch Orthop Trauma Surg 132:969-976. PMID: 22526195

7. Riley LH, Banovac K, Martinez OV, Eismont FJ (1994) Tissue distribution of antibiotics in the intervertebral disc. Spine 19:2619-25. PMID: 7899954

8. Rohde V, Meyer B, Schaller C, Hassler WE (1998) Spondylodiscitis after lumbar discectomy. Incidence and a proposal for prophylaxis. Spine 23:615-620. PMID: 9530794

9. Eismont FJ, Wiesel SW, Brighton CT (1987) Antibiotic penetration into rabbit nucleus pulposus. Spine 12:254-256. PMID: 3589822

10. Zhang L, Wang JC, Feng XM, Cai WH, Yang JD, Zhang N (2014). Antibiotic penetration into rabbit nucleus pulposus with discitis. Eur J Orthop Surg Traumatol 24:453-458. doi: 10.1007/s00590-013-1317-8.

11. Scuderi GJ, Greenberg SS, Banovac K, Martinez OV, Eismont FJ (1993) Penetration of glycopeptide antibiotics in nucleus pulposus. Spine 18:2039-2042. PMID: 8272956

12. Komatsu M, Takahata M, Sugawara M, Takekuma Y, Kato T (2010) Penetration of linezolid into rabbit intervertebral discs and surrounding tissues. Eur Spine J 19:2149-2155. doi: 10.1007/s00586-010-1548-x.

13. Thomas Rde W, Batten JJ, Want S, McCarthy ID, Brown M, Hughes SP (1995) A new in-vitro model to investigate antibiotic penetration of the intervertebral disc. J Bone Joint Surg Br 77:967-970. PMID: 7593116

14. Gibson MJ, Karpinski MR, Slack RC, Cowlishaw WA, Webb JK (1987) The penetration of antibiotics into the normal intervertebral disc. J Bone Joint Surg Br 69:784-786. PMID: 3680343

15. Shanmugam S, Acharya LD, Mallayasamy SR, Rao A, Khan SA, Rajakannan T (2010) Study of tissue and the plasma concentration of cefotaxime to assess its stability for prophylaxis in cholecystectomy. Journal of Clinical and Diagnostic Research 4:2410-2415.

16. Walters R, Rahmat R, Fraser R, Moore R (2006) Preventing and treating discitis: cephazolin penetration in ovine lumbar intervertebral disc. Eur Spine J 15.1397-1403. PMID: 16830132

17. El-Gindi S, Aref S, Salama M, Andrew J (1976) Infection of intervertebral discs after operation. J Bone Joint Surg Br 58:114-116. PMID: 1270487

18. Hamdan TA (2012) Postoperative disc space infection after discectomy: A report on thirty-five patients. Int Orthop 36: 445-450. doi: 10.1007/ s00264-011-1430-4.

19. Silber JS, Anderson DG, Vaccaro AR, Anderson PA, Mccormick P (2002) Management of post procedural discitis. Spine J 2:279-287. PMID: 14589480

20. Sharma SK, Jones JO, Zeballos PP, Irwin SA, Martin TW (2009). The prevention of discitis during discography. Spine J 9: 936-943. doi: 10.1016/j.spinee.2009.06.001

21. Snell RS, ed. (2012). Clinical anatomy by regions, 9th edition, Wolters Kluwer|Lippincott Williams\& Wilkins, Baltimore, Philadelphia.

22. Cai HX, Liu C, Fan SW (2011) Routinely using prophylactic antibiotic may not effectively prevent intervertebral disc infection: a new strategy to preventing postoperative intervertebral disc infection. Med hypothesis 76:464- 466. doi: 10.1016/j.mehy.2010.11.021.

23. Andrews JM (2001) Determination of minimum inhibitory concentrations. J Antimicrob Chemother 48 Suppl; 1:5-16. PMID: 11420333

24. Guiboux JP, Cantor JB, Small SD, Zervos M, Herkowitz HN (1995). The effect of prophylactic antibiotics on iatrogenic intervertebral disc infections. a rabbit model. Spine 20:685-688. PMID: 7604344.

25. North American Spine Society, https://www.spine.org/ResearchClinicalCare/ClinicalGuidelines.aspx. Clinical guidelines(2013).

26. Currier BL, Banovac K, Eismont FJ (1994) Gentamicin penetration into normal rabbit nucleus pulposus. Spine 19:2614-2618. PMID: 7899953

27. Fraser RD, Osti OL, Vernon-Roberts B (1989) Iatrogenic discitis: the role of intravenous antibiotics in prevention and treatment. An experimental Spine 14:1025-1032. PMID: 2781408

28. Köroğlu A, Acar O, Ustün ME, Tiraş B, Eser O (2001) The penetration of cefoperazone and sulbactam into the lumbar intervertebral discs. J Spinal Discord 14:453-454. PMID: 11586148 